\title{
Successional pathways in Swiss mountain forest reserves
}

\section{Journal Article}

Author(s):

Heiri, Caroline; Wolf, Annett; Rohrer, Lukas; Brang, Peter; Bugmann, Harald

Publication date:

2012-03

Permanent link:

https://doi.org/10.3929/ethz-b-000047315

Rights / license:

In Copyright - Non-Commercial Use Permitted

Originally published in:

European Journal of Forest Research 131(2), https://doi.org/10.1007/s10342-011-0525-1 


\title{
Successional pathways in Swiss mountain forest reserves
}

\author{
Caroline Heiri · Annett Wolf • Lukas Rohrer • \\ Peter Brang $\cdot$ Harald Bugmann
}

Received: 7 June 2010/Revised: 6 February 2011/ Accepted: 29 April 2011/Published online: 24 May 2011

(C) Springer-Verlag 2011

\begin{abstract}
Knowledge on the natural dynamics of Norway spruce-European silver fir forests is scarce, but is of high importance for the sustainable management of these ecosystems. Using a unique data set from five forest reserves in the Swiss Alps that covers up to 35 years, we elucidated communalities and differences in stand structure and species composition across the reserves and over time and investigated the role of site conditions versus intrinsic forest dynamics. For the early and late successional phases, we found a clear relationship between stand structure (diameter distributions) and species composition. Two pathways of early succession were evident as a function of the disturbance regime. Thus, the spatial extent of disturbances in spruce-fir forests strongly determines the pathway in early succession. Contrary to earlier descriptions of clearly distinguishable optima phases, our data did not reveal a relationship between stand structure and species composition for the early, mid-, and late optimum phases. Although the reserves investigated here are characterized by highly different climatic and soil conditions, their
\end{abstract}

Communicated by Klaus Puettmann.

Electronic supplementary material The online version of this article (doi:10.1007/s10342-011-0525-1) contains supplementary material, which is available to authorized users.

A. Wolf · L. Rohrer · H. Bugmann

Forest Ecology, Institute of Terrestrial Ecosystems, Department of Environmental Sciences, Swiss Federal Institute of

Technology Zurich, 8092 Zurich, Switzerland

C. Heiri $(\square) \cdot$ P. Brang

WSL Swiss Federal Institute for Forest, Snow and Landscape Research, Zürcherstrasse 111, 8903 Birmensdorf, Switzerland e-mail: caroline.heiri@wsl.ch temporal development was found to fit well into a single successional scheme, suggesting that in spruce-fir mountain forests, the life-history strategies of the tree species may have a stronger influence on successional trajectories than site conditions per se.

Keywords Abies alba - Forest succession · Long-term forest monitoring - Mountain forest - Picea abies . Structural development $\cdot$ Succession theory . Temporal dynamics

\section{Introduction}

The understanding of successional pathways has been a major focus of ecological research for over a century, and several theories explaining succession have been developed (e.g., Clements 1936; Gleason 1939; Remmert 1991; Watt 1947; cf. Finegan 1984). To evaluate the usefulness of these theories, many studies were conducted over the last several decades, investigating both primary and secondary succession in different ecosystems (e.g., Pickett et al. 2009; Tilman 1987; van der Maarel 2005 for vegetation dynamics in general, and e.g., Korpel' 1995; Leibundgut 1993; Zukrigl 1991 for forest dynamics in particular). A common problem for investigating forest succession is that these ecosystems develop very slowly, such that the relevant time scale exceeds the duration of a research career (Franklin 1989). Hence, for many forest types, a conclusive picture of the pathways of natural succession is still lacking.

Forests in Europe were strongly influenced by humans for centuries, often even for more than 2,000 years (Peterken 1996). Thus, only few areas remain where natural forest development can be observed and the different 
pathways of forest succession can be investigated in the absence of strong human influences. European beech ( $\mathrm{Fa}$ gus sylvatica) forest communities are the most widespread forest type in western and central Europe (Peterken 1996), and there are many studies investigating natural beech forest dynamics either in undisturbed forest remnants (mainly in eastern Europe) or in near-natural beech forests that have experienced only a low intensity of human disturbance at least over the last 100-200 years (in northwestern and central Europe). Most of these studies focused on structural dynamics in general (e.g., Commarmot and Bachofen 2005; Meyer et al. 2000; Piovesan et al. 2005; Tabaku 2000) or on gap dynamics in particular (e.g., Butler Manning 2007; Koop and Hilgen 1987). Other studies investigated specific drivers of succession, for example, (1) light conditions at the forest floor and the resulting regeneration pattern with respect to the structural dynamics of a natural beech forest (Emborg 1998), (2) the development of tree recruitment and the spatial distribution of tree species (Wolf 2005), or (3) the temporal development of tree species richness (Heiri et al. 2009). A few studies, however, attempted to develop a general scheme of succession in beech forests (cf. Korpel' 1995; Leibundgut 1993; Remmert 1991).

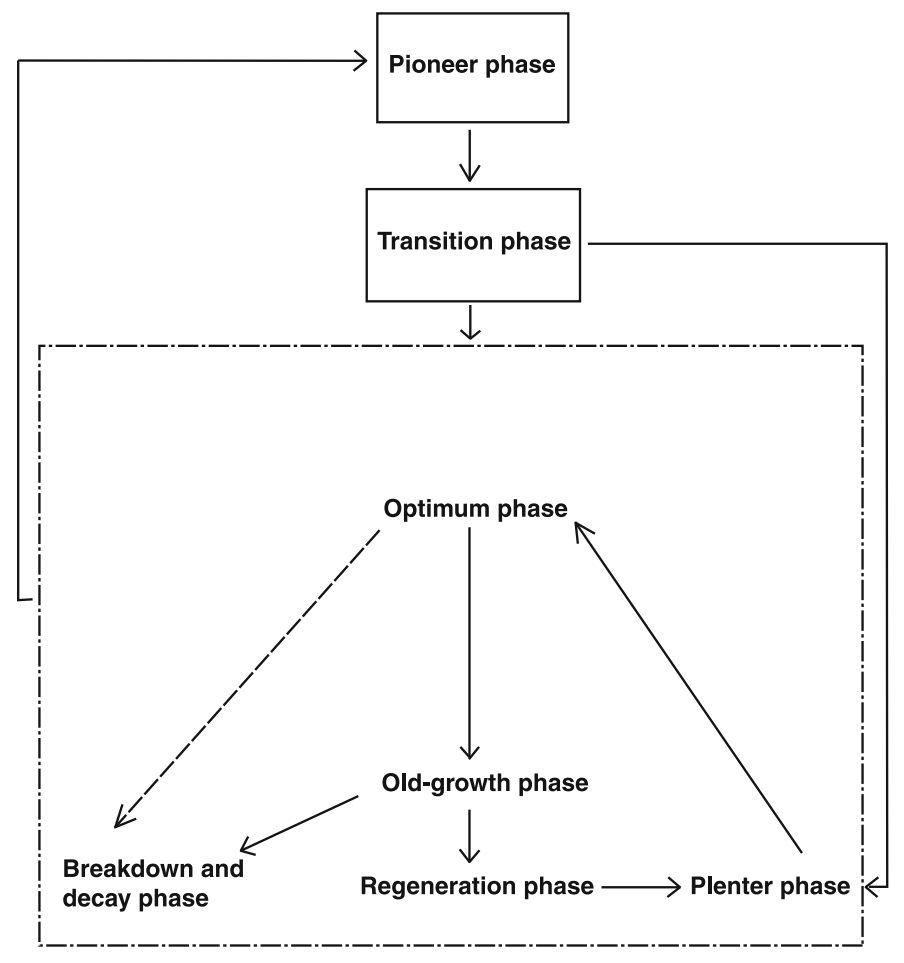

Fig. 1 Schemes of natural forest dynamics. a Natural succession of spruce-fir-beech forests, redrawn from Leibundgut (1993). b Adjusted scheme of forest dynamics for spruce-fir forests, as inferred from the analysis of the here investigated permanent plots. Numbers and colors represent the positions of the cluster groups (species composition) in
Research on higher-elevation forests has mainly focused on pure Norway spruce (Picea abies) and mixed spruce-fir (Abies alba)-beech forests. For example, Mayer and Neumann (1981) investigated two mountain spruce-fir-beech forests in Austria (Rothwald) and Croatia (Čorkova Uvala); they described the stand structure of different developmental phases and proposed a qualitative successional cycle for these forests. Leibundgut (1982, 1993) and Korpel' (1995) refined this scheme based on data from several near-natural (sensu Peterken 1996) spruce-fir-beech forests in central and eastern European mountains. They suggested that beech/fir alternations and hence the decreasing abundance of fir that was observed in some of the investigated forests over the past decades can be interpreted as part of this natural cyclical development. Podlaski (2004), however, has viewed fir decline in the 1960s and the recovery of the species in the 1980s as an "untypical" development period; thus, he modified the general scheme of spruce-fir-beech forest dynamics developed by Leibundgut (1982, 1993) and Korpel' (1995) by introducing additional stages, expecting to generalize the phase conception.

Throughout the present paper, we use the classification of developmental stages proposed by Leibundgut (1993; cf. Fig. 1a), although we are aware that other models with

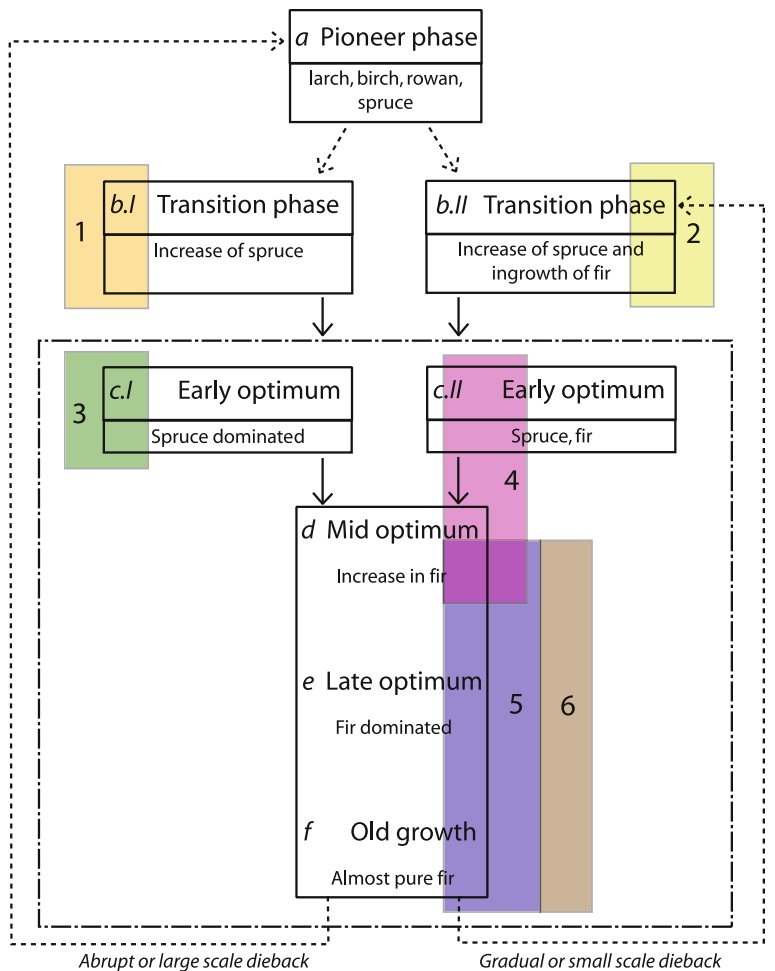

the succession cycle (for details on cluster groups see Table 2). Solid lines in $\mathbf{b}$ indicate transitions observed in the data; dotted lines represent transitions inferred from theory. It should be noted that distances between boxes do not imply any particular time scale 
different nomenclatures exist (e.g., Koop and Hilgen 1987; Korpel' 1995; Mayer and Neumann 1981; Remmert 1991 in Europe; Coomes and Allen 2007 and Oliver and Larson 1996 in North America). When doing so, we do not wish to imply that the Leibundgut classification is better than any other classification, but it has found widespread use in the European forest literature.

In the successional schemes of higher-elevation forests, beech-free Norway spruce-silver fir forests are either treated as a sub-association or disregarded entirely, mainly because quantitative knowledge on the dynamics of natural spruce-fir forests in central and western Europe is rare. The few studies focusing on spruce-fir forests have emphasized their classification and phyto-sociological description (Ellenberg and Klötzli 1972; Horvat et al. 1974; Kuoch 1954; Mayer 1974; Walentowski 1998). To date, the extensive work by Leibundgut $(1982,1993)$ is the point of reference regarding stand dynamics of spruce-fir forests. As a case study, Leibundgut (1982, 1993) described the natural dynamics of the forest reserve Derborence (Switzerland), one of the last nearly untouched spruce-fir forests in the Alps. Based on his analysis of four representative permanent plots, he incorporated this spruce-fir forest into his scheme of successional dynamics for spruce-fir-beech forests (Fig. 1a). According to Leibundgut (1993), during the "pioneer" and "transition" phases, larch (Larix decidua) dominates the stand, intermixed with spruce in the mid- and understory. A pure spruce stand often follows the transition phase, unless the pioneer forest is breaking up gradually or spruce is developing slowly compared with fir. In this latter case, fir will become co-dominant with spruce, and the stand will ultimately develop into a well-structured, multi-storied spruce-fir forest ("Plenterwald"-like). During this phase, fir dominance increases continuously, leading to fir-dominated "optimum" and "ageing" phases. The breakdown of parts of the stand enables light-demanding tree species to establish (larch, birch [Betula sp.]), which leads to a pioneer-like forest phase that closes the cycle.

A considerable fraction of European mountain forests belong to the spruce-fir forest associations (e.g., $13 \%$ of the forest area in Switzerland; Wohlgemuth et al. 2008); therefore, there is dire need for a more in-depth investigation of natural dynamics in this forest type. To this end, we evaluate the validity of Leibundgut's (1993) successional scheme in both space and time, based on a unique data set that is part of an extensive network of forest reserves in Switzerland. Our data are derived from 36 permanent plots, thereof 17 from Derborence (note that only 3 overlap with Leibundgut's study), the other 19 from four other forest reserves in the Swiss Alps within the spruce-fir(-larch) phyto-sociological associations. As data were collected at least twice in these reserves and cover up to 40 years, we were able to also analyze the temporal development of stand structure and species composition, unlike Leibundgut (1993) whose work was restricted to one single inventory. Although the time span covered by the data is still short compared with the lifetime of forest trees, our approach is highly valuable for inferring successional dynamics, especially since the investigated plots cover a wide range of successional phases.

Our overall aims are to quantify the observed patterns of stand structure and species composition and their temporal changes, and to use these findings to test Leibundgut's (1993) scheme of succession in spruce-fir forests.

To this end, we investigate stand structure and species composition across a wide range of permanent plots from different forest reserves within the group of sprucefir(-larch) forests. More specifically, (1) we group the plots according to their species composition and determine whether these groups can be positioned within the successional scheme of Leibundgut (1993). (2) We investigate the temporal development of stand structure and species composition of each permanent plot in order to determine the direction of the observed changes. (3) We compare the observed trends with the successional changes suggested by Leibundgut (1993) to test the validity of his scheme. (4) We discuss whether the dynamics of permanent plots from ecologically different locations (forest types) follow a common scheme of successional trajectories, or whether site-specific effects are overwhelming any attempt of generalization.

\section{Materials and methods}

\section{Forest inventory data}

The study areas are part of the forest reserve network established by the Swiss Federal Institute of Technology Zurich (ETHZ) since the late 1940s; today, they are maintained jointly by ETHZ and the Swiss Federal Institute for Forest, Snow and Landscape Research WSL (for details, see Brang et al. 2008; Heiri et al. 2009). Data were collected on two levels of intensity: compartments (data not used here) and permanent plots. At the time of their establishment, permanent plots were chosen to represent stands characterized by a homogenous phyto-sociological association, microtopography, developmental stage, and stand structure. In these plots (mostly $0.1-0.6$ ha in size), all trees with a diameter at breast height $\left(\mathrm{dbh}^{1}\right) \geq 4.0 \mathrm{~cm}$ were individually and repeatedly inventoried, and their species and condition (dead or alive) recorded. Additional tree parameters followed the IUFRO (International Union of Forest Research Organizations) inventory template for

\footnotetext{
${ }^{1}$ Measured $1.30 \mathrm{~m}$ above ground.
} 
natural forests as described by Leibundgut $(1959,1962)$. They include the canopy layer of each tree in relation to the tallest trees in its surrounding in thirds, with "understory" being assigned to each tree within the lower third and "overstory" to each tree within the upper third of the stand height, respectively. Although the data come with limitations that are typical for such long-term empirical research (e.g., variable plot and reserve sizes, variable inventory intervals), this data set is, nevertheless, unique in terms of the number of unmanaged forest plots and the variety of forest types included, the time span covered by the investigations and the high level of detail, especially in the intensively monitored permanent plots.

\section{Study sites}

For our study, only permanent plots in spruce-fir(-larch) phyto-sociological associations were selected. Additionally, pure spruce forests were included to evaluate whether their structural dynamics are comparable with those in spruce-fir forests, as implicitly assumed in the plant functional type concept used by some computer models (e.g., dynamic global vegetation models). Thirty-six permanent plots in five forest reserves in the upper montane and subalpine zones met these criteria (Fig. 2). The reserves of Bödmerenwald and Leihubelwald are located in the northern Pre-Alps, characterized by an oceanic climate with moderate daily and seasonal temperature fluctuations, and an annual precipitation sum of 2,314 and 1,772 mm, respectively (Table 1; spatially interpolated climate data from Land Use Dynamics at WSL, Thornton et al. 1997). Derborence and Scatlè are located in the northern intermediate Alps, which lie in the transition zone between oceanic and continental climate with higher daily and seasonal temperature fluctuations than in the northern preAlps, and less precipitation $\left(1,487\right.$ and 1,547 mm year ${ }^{-1}$,

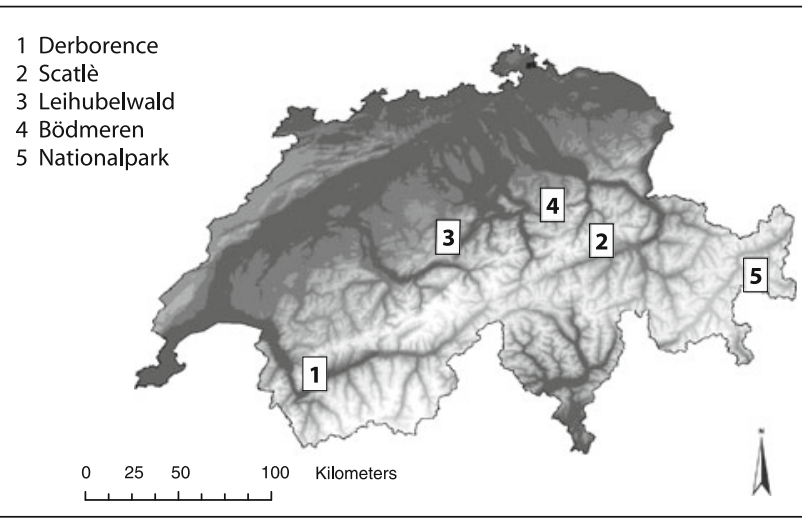

Fig. 2 Topographical map of Switzerland. Low elevations, dark; high elevations, white. The locations of the investigated forest reserves are marked with numbers. ${ }^{\odot} 2005$ swisstopo respectively). Lastly, the forest of Plan Praspöl has a continental climate with high daily and seasonal temperature fluctuations and relatively low precipitation sum (895 $\mathrm{mm} \mathrm{year}^{-1}$; for details, see Table 1).

Bödmerenwald and Scatlè are pure spruce forests. Their near-natural state is largely a consequence of the difficult accessibility due to the peculiar site conditions: Bödmerenwald lies within a large karst area, and Scatlè is located on a steep east-facing slope on the debris of an early Holocene rockslide. Derborence, which is difficult to access as well due to a large rockfall in historic times, and Leihubelwald are mixed spruce-fir forests, with some admixed larch (Derborence) or beech (Leihubelwald; for details of phyto-sociological associations, see Table 1). Plan Praspöl is a spruce-larch forest. Although primeval forests in the strict sense do not exist anymore in the Alps or elsewhere in western Europe, four out of the five selected forests are in remote areas. The reserves Derborence, Bödmerenwald, and Scatlè have never been exploited systematically and have therefore maintained a primeval character. At most single trees were harvested sporadically, and since the establishment of the reserves, timber harvesting has stopped completely. The forests of the lower Engadin Valley, where Plan Praspöl is located (part of the Swiss National Park), were probably clear-cut twice until about 100 years ago. Since around 1900, all forest exploitation in the park area has ceased (Parolini 1995). According to Gross (1982), Leihubelwald has been managed until the 1920s, but since then it has been left to develop naturally as well.

\section{Data analysis}

For the analyses, we selected all permanent plots that have data from more than one inventory and a minimum size of $0.1 \mathrm{ha}$, which resulted in the dismissal of plot D7 in Derborence with only one field campaign and plot D3 in Derborence, which was too small. Since the focus of this study was on forests dominated by spruce, spruce-fir or fir (including the pioneer phase with larch), but not on firbeech forests, we excluded permanent plots consisting of more than $30 \%$ beech (based on the Importance Value, see below). Two plots in Leihubelwald (L2 and L3) met this criterion.

The number of inventories differs between the selected permanent plots, ranging from two (Plan Praspöl) to four (Scatlè and parts of Derborence; Table 1). For the analysis of temporal trends, only the first and last inventories of each permanent plot were selected so as to maximize the time span covered in the analysis.

Our data set features a nested structure, with permanent plots being located within reserves. However, the cluster analysis yielded well-mixed groups in terms of reserves. 
Table 1 Detailed site information on the investigated forest reserves

\begin{tabular}{|c|c|c|c|c|c|}
\hline & Derborence & Scatlè & Bödmerenwald & Leihubelwald & $\begin{array}{l}\text { Plan Praspöl } \\
\text { (Nationalpark) }\end{array}$ \\
\hline $\begin{array}{l}\text { Size of forest within } \\
\text { reserve [ha] }\end{array}$ & 22.3 & 9.13 & 5 & 23.79 & 26 \\
\hline $\begin{array}{l}N \text { permanent plots used/ } \\
\text { total area covered [ha] }\end{array}$ & $17 / 6.22$ & $2 / 6.36$ & $4 / 4.84$ & $11 / 4.08$ & $2 / 0.92$ \\
\hline Altitude [m a.s.1.] & $1440-1660$ & $1600-2000$ & 1500 & $1080-1270$ & 1650 \\
\hline $\begin{array}{l}\text { Mean annual } \\
\text { temperature }\left[{ }^{\circ} \mathrm{C}\right]^{\mathrm{a}}\end{array}$ & 4.6 & 3.6 & 3.7 & 6.0 & 2.6 \\
\hline $\begin{array}{l}\text { Annual precipitation } \\
\text { sum }[\mathrm{mm}]^{\mathrm{a}}\end{array}$ & 1487 & 1547 & 2314 & 1772 & 895 \\
\hline Aspect & NW & $\mathrm{E}$ & - & E-SE & NE \\
\hline Bedrock & Limestone & Verrucano & $\begin{array}{l}\text { Limestone } \\
\text { (karst) }\end{array}$ & Flysch & Dolomite \\
\hline Soil & Cambisol & Regosol & Lithosol & Cambisol & Rendzina \\
\hline $\begin{array}{l}\text { Main forest } \\
\text { association }(\mathrm{s})^{\mathrm{b}}\end{array}$ & $\begin{array}{l}\text { Adenostylo alliariae- } \\
\text { Abieti-Piceetum } \\
\text { typicum }\end{array}$ & $\begin{array}{l}\text { Homogyno- } \\
\text { Piceetum } \\
\text { vaccinietosum }\end{array}$ & $\begin{array}{l}\text { Homogyno- } \\
\text { Piceetum }\end{array}$ & $\begin{array}{l}\text { Equiseto sylvatici-Abieti- } \\
\text { Piceetum; Sphagno- } \\
\text { Piceetum }\end{array}$ & $\begin{array}{l}\text { Larici-piceetum; } \\
\text { Homogyno- } \\
\text { piceetum }\end{array}$ \\
\hline \multirow[t]{4}{*}{ Inventory campaigns } & 1955 (partly) & 1965 & 1973 & 1973 & 1978 \\
\hline & 1967 (partly) & 1977 & 1988 & 1983 & 1993 \\
\hline & $1981 / 82$ & 1989 & 2003 & 1995 & \\
\hline & 1990/91 & 2006 & & & \\
\hline
\end{tabular}

a Data source: Land Use Dynamics, WSL, Switzerland (average 1960-2006; Thornton et al. 1997)

b Phyto-sociological classification following Ellenberg and Klötzli (1972)

For example, the two reserves containing the largest number of plots (Derborence and Leihubelwald) are represented well in the vast majority of cluster groups (Derborence in 5 and Leihubelwald in 4 out of 6 groups), indicating that all successional stages are found across these reserves. If nesting was a problem, we would expect a clustering of the reserves, which is clearly not the case. Therefore, nesting was not considered further in the analysis.

Data were analyzed using the statistical computing environment R, Version 2.7.1 (R Development Core Team 2008).

\section{Cluster analysis}

Importance Values $(I V=$ [relative density + relative basal area] $/ 2 \times 100$ ) were calculated for each species to characterize the tree species composition of each permanent plot and its change over time (Parker et al. 1985). A cluster analysis was conducted to group the permanent plots according to their respective species composition based on the $I V$. Thereby, Euclidian distance was used, applying the furthest neighbor linkage method (Leyer and Wesche 2007). The analysis was conducted for the first and the last inventory separately. As both analyses showed an identical clustering, i.e., the same groups were identified for both points in time, we only present the results of the first inventory.

\section{Diameter structure}

To analyze diameter distributions, stem counts were pooled in $4-\mathrm{cm} \mathrm{dbh}$ classes. To group the permanent plots according to their dbh distribution, the Shannon-Weaver index, $S H$, was calculated as a measure of tree size diversity: $\mathrm{SH}=\sum_{i}^{N}\left(-\ln \pi_{i}\right) \cdot \pi_{i}$, where $N$ is the number of dbh classes and $\pi_{i}$ is the relative abundance of trees in the $i$ th dbh class (Shannon and Weaver 1949; Neumann and Starlinger 2001). The minimum value of zero would characterize a stand in which all trees are in a single dbh class, whereas the maximum value of $\ln (N)$ results when the trees are evenly distributed over all classes. To allow for comparisons across the 36 permanent plots, Shannon evenness was calculated by standardizing the Shannon index: the ratio between the observed and the plot-specific maximum diversity was calculated, thus limiting the index to the range between zero and one (Lexerød and Eid 2006).

To test for significant differences in structural diversity (according to $\mathrm{SH}$ ) between the clusters of different species composition, the non-parametric Kruskal-Wallis test was used (Kruskal-Wallis one-way analysis of variance by ranks, Siegel and Castellan 1988). A significant value for 
the Kruskal-Wallis test indicates that at least one of the groups is different from at least one of the others. To identify groups that differ from each other, and as an approach to group the permanent plots according to their dbh distribution, a multiple comparison test after KruskalWallis was used (Giraudoux 2008; Siegel and Castellan 1988). This test is basically a pairwise comparison with error adjustments for multiple a posteriori tests: those pairs of groups that have observed differences higher than a critical value are considered to be statistically different at the given probability ( $P$ level). The Kruskal-Wallis test and the subsequent multiple comparison test were also applied to the dbh distributions per se.

Two key features that characterize a diameter distribution of a plot are (1) the amount of "small" trees and (2) the number of occupied dbh classes, or-a related variable- the maximum size of "large" trees as reference for the vertical structure, age and developmental phase. However, none of the above indices are able to explicitly distinguish these specific aspects. Therefore, we defined a structure index $(S I)$ that contrasts the number of occupied dbh classes with the relative number of trees with a dbh $<20 \mathrm{~cm}$, to be plotted in 2D-space (cf. Fig. 5). A threshold of $\mathrm{dbh}<20 \mathrm{~cm}$ was selected for this study because tests with other threshold values showed comparable results. Young stands with high numbers of small trees and hardly any large dbh values would be located at the top left of Fig. 5, whereas old stands with few small but many large trees are found at the bottom right of the graph. Stands with high structural diversity (such as "plenter" stands, i.e., presence of trees of all sizes; Rubin et al. 2006) would be located in the middle/top-right area of the plot.

\section{Multivariate analysis}

To determine the direction and rate of succession, changes in tree species composition over time were analyzed using principal components analysis (PCA) (Legendre and Legendre 1998). To investigate whether the tree species composition of the permanent plots was homogenous or whether the understory and overstory composition differed (which would indicate an impending change), understory and overstory tree species composition for each permanent plot for the first inventory were analyzed separately. The Importance Value was chosen as a measure of tree species abundance. Ordination of multiple plot measurements over time (two per plot) allowed for an estimation of plot trajectories and patterns of community change in ordination space. Analyzing understory and overstory tree species composition separately enabled us to identify whether the two layers developed in similar or different ways. The latter would indicate a future change in species composition and thereby possibly a shift in the developmental phase.
Testing the robustness of results using a homogenized data set

As our data set was rather heterogeneous in plot size, soil conditions and stand history, we repeated all analyses with a smaller, but more homogeneous data set. We dismissed pure spruce plots as well as plots from reserves where fir does not occur, mainly due to climatic reasons. This selection also homogenized the data set in terms of plot size. The new data set contained 26 permanent plots from the two reserves with the largest number of plots: Derborence (16) and Leihubelwald (10). The comparable number of plots from these two reserves removed any possible "reserve effect". The results from the cluster analysis and the PCAs were identical for the homogenized and the full data set, and therefore only the results from the full data set are presented below. The comparison between the two analyses showed that our results are robust and not influenced by differences in plot size, site conditions, and site history; thus, a "reserve bias" can be ruled out.

\section{Results}

\section{Cluster analysis}

The cluster analysis of the permanent plots yielded seven clusters (Fig. 3) that differed strongly in the proportion of spruce, fir, and larch (Table 2). Plot D11 formed a cluster on its own, and statistical analyses are not valuable with a sample size of $N=1$. Therefore, only the six clusters with more than one member were further considered. Plot L5clearly separated from the other plots in group 3-has an extraordinarily high amount of sycamore (Acer pseudoplatanus, 20\%); this species is only intermixed at low levels in the other plots. Therefore, plot L5 was excluded from further analysis as an outlier.

\section{Stand structure}

Stand characteristics such as stem number and basal area differed considerably between the plots. However, when grouped by tree species composition as determined by the cluster analysis, a clear trend in the mean values was evident, with pioneer forests such as spruce-larch and sprucelarch-fir stands having high stem numbers and low basal area, whereas later successional phases such as the pure spruce and the fir-dominated stands showed low stem numbers and-in the case of fir-dominated forests-high basal area (Table 3). The Kruskal-Wallis and its follow-up tests showed significant differences $(P<0.05)$ in stem numbers between pure spruce and spruce-fir forests for both the first and the last inventory, as well as between pure 
Fig. 3 Dendrogram of cluster analysis including all permanent plots based upon tree species composition (IV) for the first inventory. Similarity measure: euclidean distance; linkage method: furthest neighbor. Dotted line indicates where the dendrogram was cut in order to get the seven groups.

$L$ Leihubelwald, $D$ Derborence, $N$ Nationalpark, $B$ Bödmeren, $S$ Scatlè. Large numbers refer to the cluster groups according to Table 2, small numbers are plot numbers. Plots not used for further analysis are marked with an asterisk (*)

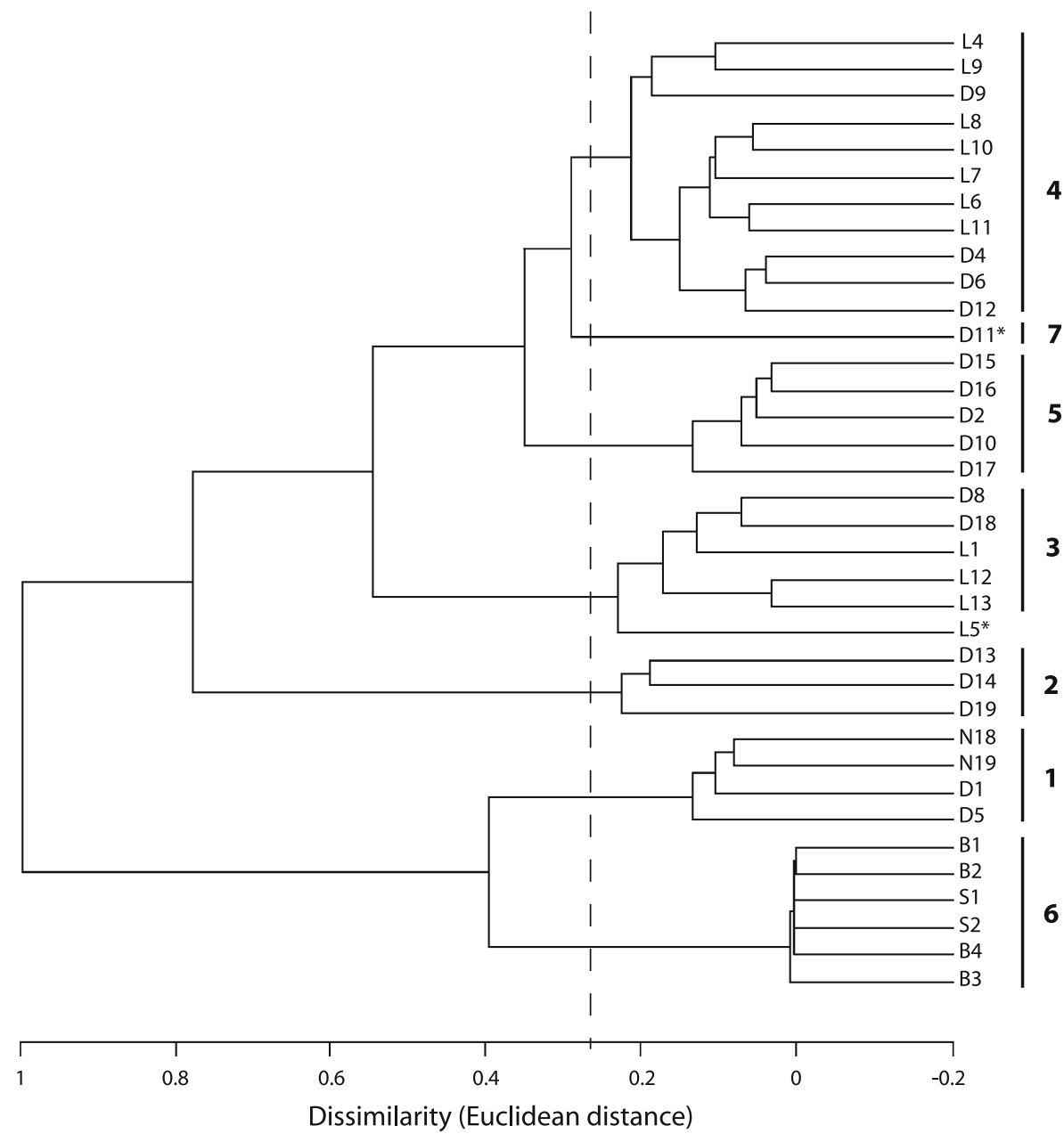

Table 2 Mean values and standard error of the relative tree species composition per cluster group based on the importance value (IV), and its change over time for the main tree species spruce (Spr), fir (Fir), and larch (Lar)

\begin{tabular}{|c|c|c|c|c|c|c|c|c|c|c|c|c|c|c|c|c|}
\hline \multirow[t]{2}{*}{ Cluster group } & \multicolumn{8}{|c|}{ Species composition first inventory } & \multicolumn{8}{|c|}{ Species composition last inventory } \\
\hline & $\mathrm{Spr}$ & $\pm S E$ & Fir & $\pm S E$ & Lar & $\pm S E$ & Other & $\pm S E$ & Spr & $\pm S E$ & Fir & $\pm S E$ & Lar & $\pm S E$ & Other & $\pm S E$ \\
\hline 1 Spruce-larch & 72 & 2 & 1 & 1 & 18 & 2 & 8 & 2 & 74 & 1 & 2 & 1 & 17 & 2 & 8 & 2 \\
\hline 2 Spruce-larch-fir & 25 & 3 & 13 & 1 & 49 & 4 & 13 & 7 & 23 & 5 & 13 & 4 & 46 & 2 & 16 & 8 \\
\hline 3 Spruce-dominated & 58 & 1 & 30 & 1 & 1 & 1 & 11 & 2 & 56 & 2 & 32 & 2 & 2 & 2 & 11 & 2 \\
\hline 4 Spruce-fir & 42 & 1 & 48 & 1 & 1 & 0 & 9 & 2 & 37 & 2 & 52 & 2 & 1 & 1 & 11 & 2 \\
\hline 5 Fir-dominated & 34 & 2 & 63 & 2 & 1 & 0 & 2 & 1 & 32 & 2 & 64 & 2 & 2 & 1 & 2 & 1 \\
\hline 6 Pure spruce & 100 & 0 & 0 & 0 & 0 & 0 & 0 & 0 & 100 & 0 & 0 & 0 & 0 & 0 & 0 & 0 \\
\hline
\end{tabular}

spruce and spruce-larch stands for the last inventory. For basal area, significant differences could be found in the first inventory only, namely between pure spruce and fir-dominated forests, and between fir-dominated and spruce-larchfir stands.

Only fir-dominated and spruce-larch stands differed significantly from each other $(P<0.05)$ with regard to the density of large living trees. However, fir-dominated forests tended to feature high numbers of large living trees, spruce-fir stands intermediate numbers, and spruce-dominated and pure spruce stands as well as stands intermixed with larch low or very low numbers (Table 3 ).

When the permanent plots were grouped according to the results of the cluster analysis, spruce-larch-fir (Fig. 4d) and pure spruce stands (Fig. 4f) showed a distinct shape of their dbh distribution. The spruce-larch-fir cluster featured 
Table 3 Mean and standard error of the major stand characteristics grouped by species composition based on the result of the cluster analysis

\begin{tabular}{|c|c|c|c|c|c|c|c|c|c|c|c|c|c|c|}
\hline & N/ha & $\pm S E$ & $\begin{array}{l}\mathrm{BA} / \mathrm{ha} \\
{\left[\mathrm{m}^{2}\right]}\end{array}$ & $\pm S E$ & $\begin{array}{l}\text { Dbh } \\
>80 \mathrm{~cm} \\
{[\mathrm{~N} / \mathrm{ha}]}\end{array}$ & $\pm S E$ & $\begin{array}{l}\text { BA } \\
\text { dead } \\
{\left[\mathrm{m}^{2} / \mathrm{ha}\right]}\end{array}$ & $\pm S E$ & $\begin{array}{l}\text { Dead } \\
\text { trees } \\
>30 \mathrm{~cm} \\
{[\mathrm{~N} / \mathrm{ha}]}\end{array}$ & $\pm S E$ & $\begin{array}{l}\% \text { dead } \\
\text { trees } \\
{[\mathrm{BA}]}\end{array}$ & $\pm S E$ & $\begin{array}{l}\% \text { dead } \\
\text { trees } \\
{[N]}\end{array}$ & $\pm S E$ \\
\hline \multicolumn{15}{|l|}{ (a) First inventory } \\
\hline Pure spruce & $383^{\mathrm{a}}$ & 34 & $47^{\mathrm{c}}$ & 4 & 4 & 1 & 2 & 1 & 6 & 3 & 4 & 1 & 11 & 2 \\
\hline $\begin{array}{l}\text { Spruce } \\
\text { dominated }\end{array}$ & 900 & 189 & 54 & 6 & 7 & 5 & 2 & 1 & 4 & 1 & 3 & 1 & 7 & 1 \\
\hline Spruce-fir & $1137^{\mathrm{a}}$ & 103 & 66 & 5 & 12 & 3 & 2 & 1 & 5 & 2 & 4 & 1 & 6 & 2 \\
\hline Fir-dominated & 646 & 43 & $83^{\mathrm{c}, \mathrm{d}}$ & 3 & $29^{\mathrm{e}}$ & 5 & 4 & 1 & 7 & 1 & 4 & 1 & 6 & 1 \\
\hline Spruce-larch & 964 & 78 & 44 & 9 & $0^{\mathrm{e}}$ & 0 & 2 & 1 & 3 & 2 & 4 & 1 & 14 & 4 \\
\hline $\begin{array}{l}\text { Spruce-larch-fir } \\
\text { (b) Last inventory }\end{array}$ & 1025 & 132 & $27^{\mathrm{d}}$ & 11 & 3 & 2 & 0 & 0 & 1 & 1 & 1 & 0 & 3 & 1 \\
\hline Pure spruce & $321^{\mathrm{a}, \mathrm{b}}$ & 48 & 45 & 4 & 7 & 1 & 7 & 2 & 30 & 7 & 14 & 3 & 19 & 3 \\
\hline $\begin{array}{l}\text { Spruce } \\
\text { dominated }\end{array}$ & 764 & 167 & 54 & 7 & 9 & 5 & 8 & 3 & 27 & 13 & 12 & 5 & 17 & 3 \\
\hline Spruce-fir & $1009^{a}$ & 104 & 60 & 6 & 13 & 3 & 10 & 1 & 35 & 6 & 15 & 2 & 15 & 2 \\
\hline Fir-dominated & 445 & 64 & 62 & 10 & 22 & 6 & 27 & 10 & 94 & 41 & 30 & 12 & 31 & 8 \\
\hline Spruce-larch & $1146^{\mathrm{b}}$ & 222 & 51 & 6 & 0 & 0 & 3 & 1 & 8 & 3 & 5 & 1 & 14 & 3 \\
\hline Spruce-larch-fir & 1074 & 127 & 29 & 9 & 3 & 2 & 1 & 1 & 6 & 3 & 4 & 1 & 7 & 2 \\
\hline
\end{tabular}

Values for (a) first inventory and (b) last inventory. Letters indicate clusters differing significantly from each other $(P>0.05)$

high amounts of small trees and few large trees (Fig. 4d), whereas the pure spruce cluster showed an even distribution of trees over the dbh classes (Fig. 4f). The other four clusters differed in the relative amount of small trees versus the presence of large diameter trees, but the shapes of their dbh distributions were not as distinct.

Only two cluster combinations differed significantly $(P<0.05)$ with respect to Shannon evenness (Table 4): pure spruce stands showed the highest value for $S H$ and differed from spruce-fir as well as from spruce-larch-fir stands, which both had significantly lower values for $S H$. The pure spruce and the fir-dominated stands were characterized by the lowest variability of Shannon evenness, whereas spruce-dominated and spruce-fir stands had much higher within-cluster variability (Table 4).

The structure index $(S I)$ allowed us to include not only the evenness of the diameter distribution but also the slope at the left side of the distribution by incorporating the relative amount of small trees (Fig. 5). Pure spruce stands were separated clearly from the other plots and were characterized by low numbers of small trees and a high number of occupied dbh classes. In contrast, spruce-larch and, to a smaller extent, spruce-larch-fir plots showed high to moderate amounts of small trees, but they occupied only few dbh classes (i.e., lack of large trees). Spruce- and firdominated as well as spruce-fir plots were difficult to separate: the fir-dominated plots tended to exhibit more occupied dbh classes, whereas the spruce-fir plots had somewhat higher numbers of small trees.
The Kruskal-Wallis test of the diameter distributions confirmed the patterns described earlier. On the one hand, the distributions of pure spruce stands, spruce-larch and spruce-larch-fir stands were classified as being significantly different, thereby clearly separating these three clusters. On the other hand, the dbh distributions of spruce-dominated, spruce-fir, and fir-dominated stands were quite similar, thus indicating a continuous structural transition within this tree species mix (see Appendix A electronic supplementary material for details).

Temporal development of stand structural attributes

In the three spruce-larch-fir stands, stem numbers and basal area slightly increased over time (see Appendix B electronic supplementary material for plot-specific data). This trend was also evident in the four spruce-larch stands for basal area, but not for stem numbers: with the exception of plot D5, stem numbers in these four stands decreased slightly over time. In the five spruce-dominated and the eleven spruce-fir stands, stem numbers decreased (with the exception of L9), and basal area decreased in eleven of these sixteen plots. Within the spruce-dominated stands, two out of five, and in the cluster of spruce-fir stands, three out of eleven plots featured an increase in basal area (Appendix B electronic supplementary material). In the six pure spruce and the four fir-dominated stands, stem numbers clearly decreased (except for plot $\mathrm{S} 1$, which is most likely due to the ingrowth of many small trees into the 
(a) Fir dominated cluster

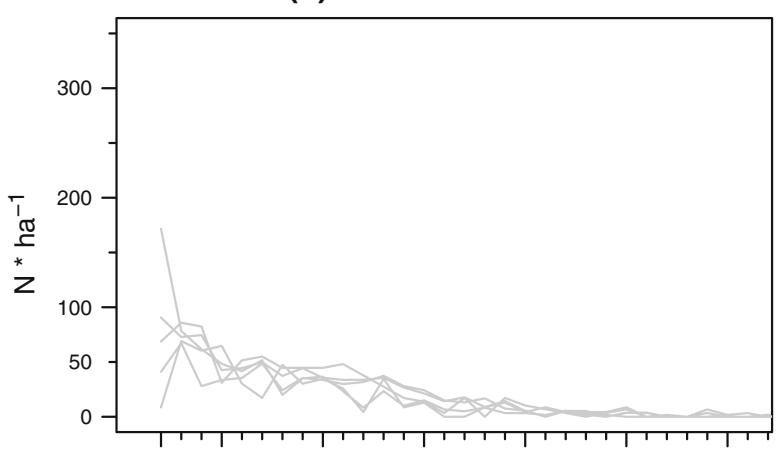

(b) Spruce-fir cluster

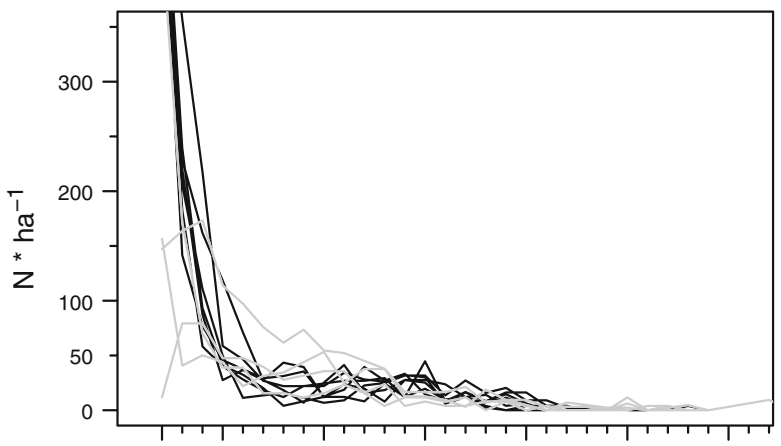

(c) Spruce dominated cluster

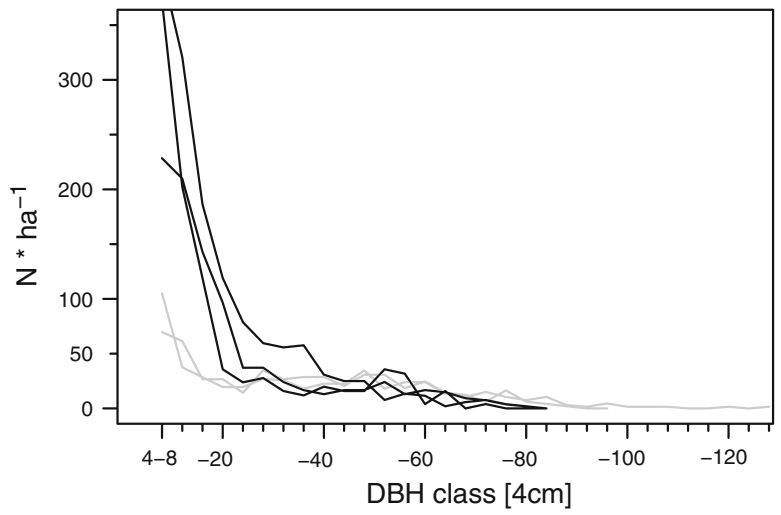

(d) Spruce-larch-fir cluster

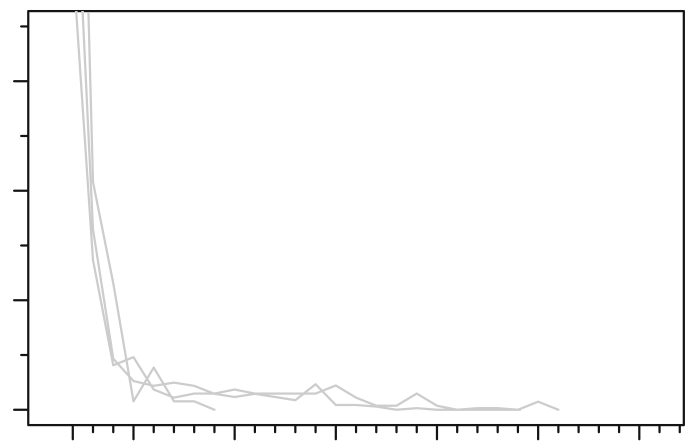

(e) Spruce-larch cluster

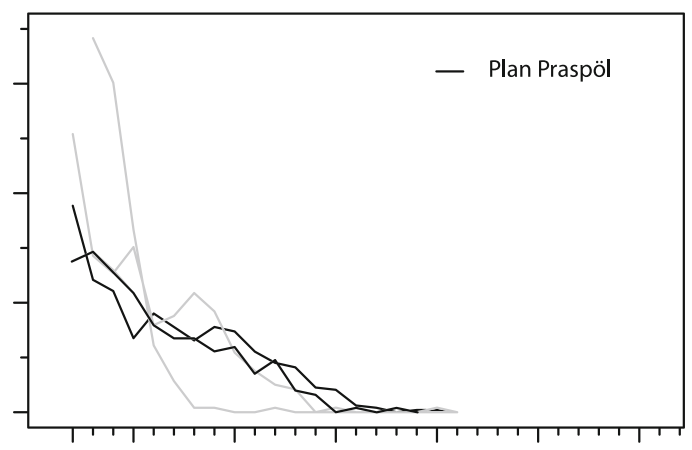

(f) Pure spruce

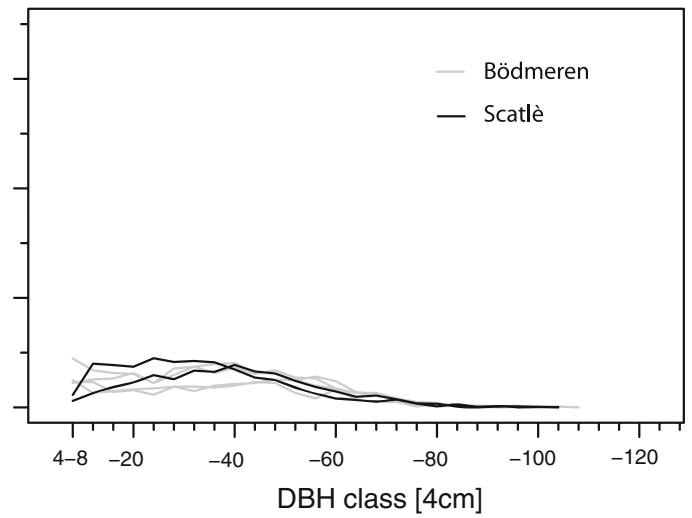

Fig. 4 Diameter distributions for the first inventory according to the groups of the cluster analysis. Grey Derborence; black Leihubelwald, unless otherwise indicated

callipering limit in an avalanche track along one edge of the plot). Basal area clearly decreased in the fir-dominated stands, except for D16, which showed a slight increase. Lastly, the pure spruce stands showed little change in basal area over time. The only plot with a clear change in basal area was B2 with a decrease from 58 to $33 \mathrm{~m}^{2} \mathrm{ha}^{-1}$, which was caused by the hurricane Vivian in 1990. Thus, over all groups stem numbers generally decreased with the exception of spruce-larch-fir stands, while basal area tended to decrease in all stands where larch was absent.

The proportion of dead trees (Table 3 ) revealed low standing dead wood amounts for spruce-larch and spruce- larch-fir stands $(<5 \%$ of total basal area), intermediate levels for pure spruce, spruce-dominated and spruce-fir stands (12-15\% of basal area), and high values for firdominated stands (ca. 30\% of basal area). The same pattern was evident in the density of large dead trees.

A strong increase in the density and basal area of dead trees between the first and the last inventory (cf. Appendix B electronic supplementary material) suggests recent natural disturbances in 13 out of the 36 plots (D2, D4, D6, D8, D10, D12, D15, D17, D18, B2, L7, L8, and L10). These quantitative interpretations are corroborated by entries in the field logs reporting vast damage by the hurricane 
Table 4 Shannon Evenness ( $\mathrm{SHrel}$ ) for the first inventory of all permanent plots, grouped by species composition according to the cluster analysis

\begin{tabular}{|c|c|c|c|c|c|c|c|c|c|c|c|c|}
\hline & \multicolumn{2}{|c|}{ Spruce } & \multicolumn{2}{|c|}{ Spruce dom } & \multicolumn{2}{|c|}{ Spruce-fir } & \multicolumn{2}{|c|}{ Fir dom } & \multicolumn{2}{|c|}{ Spruce-larch } & \multicolumn{2}{|c|}{ Spruce-larch-fir } \\
\hline & Plot & SHrel & Plot & SHrel & Plot & SHrel & Plot & SHrel & Plot & SHrel & Plot & SHrel \\
\hline & b1 & 0.93 & 11 & 0.64 & 14 & 0.52 & d2 & 0.88 & d1 & 0.86 & d13 & 0.39 \\
\hline & b2 & 0.89 & 112 & 0.73 & 16 & 0.73 & d10 & 0.75 & d5 & 0.67 & d14 & 0.58 \\
\hline & b3 & 0.91 & 113 & 0.76 & 17 & 0.62 & d15 & 0.90 & n18 & 0.87 & d19 & 0.60 \\
\hline & b4 & 0.93 & d8 & 0.88 & 18 & 0.71 & d16 & 0.88 & n19 & 0.90 & & \\
\hline & s1 & 0.83 & d18 & 0.94 & 19 & 0.59 & d17 & 0.90 & & & & \\
\hline & s2 & 0.90 & & & 110 & 0.66 & & & & & & \\
\hline & & & & & 111 & 0.69 & & & & & & \\
\hline & & & & & $\mathrm{d} 4$ & 0.85 & & & & & & \\
\hline & & & & & d6 & 0.82 & & & & & & \\
\hline & & & & & d9 & 0.68 & & & & & & \\
\hline & & & & & d12 & 0.84 & & & & & & \\
\hline Mean & & $0.90^{\mathrm{a}, \mathrm{b}}$ & & 0.79 & & $0.70^{\mathrm{a}}$ & & 0.86 & & 0.83 & & $0.52^{\mathrm{b}}$ \\
\hline $\pm S E$ & & 0.02 & & 0.05 & & 0.03 & & 0.03 & & 0.05 & & 0.07 \\
\hline
\end{tabular}

A value of zero indicates that all trees are in one diameter class, opposed to an even distribution over all classes for a value of one. Letters indicate clusters differing significantly from each other $(P>0.05)$

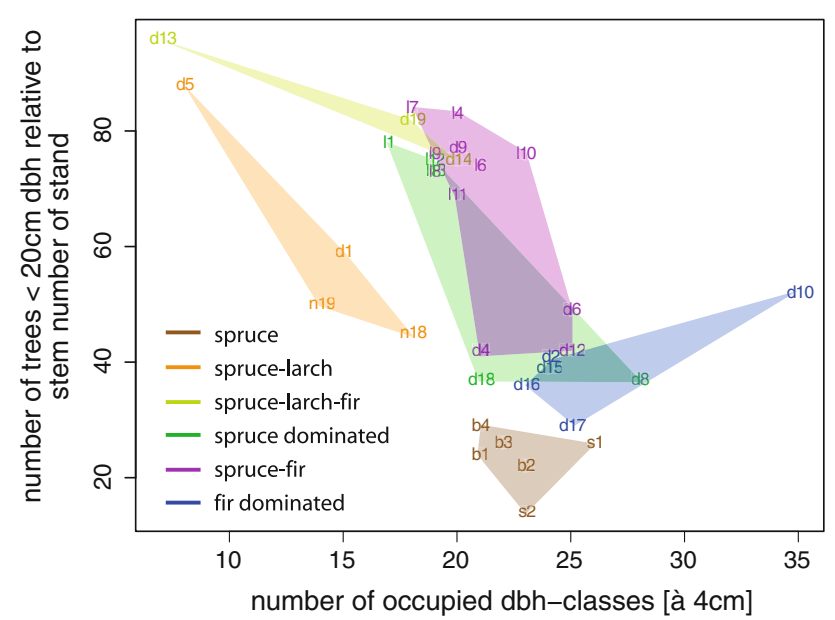

Fig. 5 Number of occupied diameter classes to relative amount of "small" trees in stand $(\mathrm{dbh}<20 \mathrm{~cm})$ as a proxy for forest stand structure for the first inventory. Plots belonging to the same cluster group are highlighted in color to emphasize a possible correlation between species composition and stand structure

Vivian in 1990 and by personal observations in the field which suggest subsequent damage by bark beetle infestations. Most of these disturbed plots are in clusters 4 (spruce-fir) and 5 (fir-dominated).

\section{Understory versus overstory tree species composition}

The first axis of the PCA showed a strong gradient from spruce to fir dominance, whereas the second axis distinguished larch-dominated stands from fir and spruce dominance, respectively (Fig. 6). Together, the first two axes accounted for $93 \%$ of the variation in species composition of the under- and overstory of the permanent plots at the time of the first inventory. The clusters were clumped, clearly separating spruce-larch, spruce-larch-fir, and pure spruce plots from mixed spruce-fir plots and those dominated by fir. The length of the arrows between over- and understory (Fig. 6) can be used as proxy to infer how much the species composition of the two layers differs. The longest arrows were found for the plots containing larch (i.e., mixtures of spruce-larch-fir and spruce-larch) followed by the spruce-fir plots. No or hardly any difference between the layers was evident for pure spruce and firdominated stands.

The direction of the arrows (Fig. 6) roughly indicates the direction of change in species composition of the stand, since today's understory (lower third of the canopy) will form the main canopy of the future forest stands, even though under- and overstory trees may be similar in age, and species-specific mortality patterns are likely to differ somewhat. Three general development trends were evident from the PCA: (1) Spruce-dominated and spruce-fir stands showed a clear trend from spruce in the upper layer toward an increase in fir dominance in the lower layer. The only exception was plot D9, which showed the reverse trend. (2) Spruce-larch stands showed a shift from larch dominance in the overstory to more spruce in the understory, whereas (3) spruce-larch-fir stands were clearly dominated by larch in the upper but tended to fir dominance in the lower layer. Exceptions were plot D1 with a tendency to more fir in the understory [for case (2)], and D13 with a more sprucedominated lower layer [for case (3)]. Fir-dominated plots 
Fig. 6 Principal component analysis (PCA) of understory and overstory tree species composition (Importance Value, first inventory) of all investigated permanent plots. Arrows connect ordinated positions of overstory and understory of the same permanent plot (arrowhead $=$ understory). Colors according to groups from cluster analysis. Vectors for major tree species are marked in grey

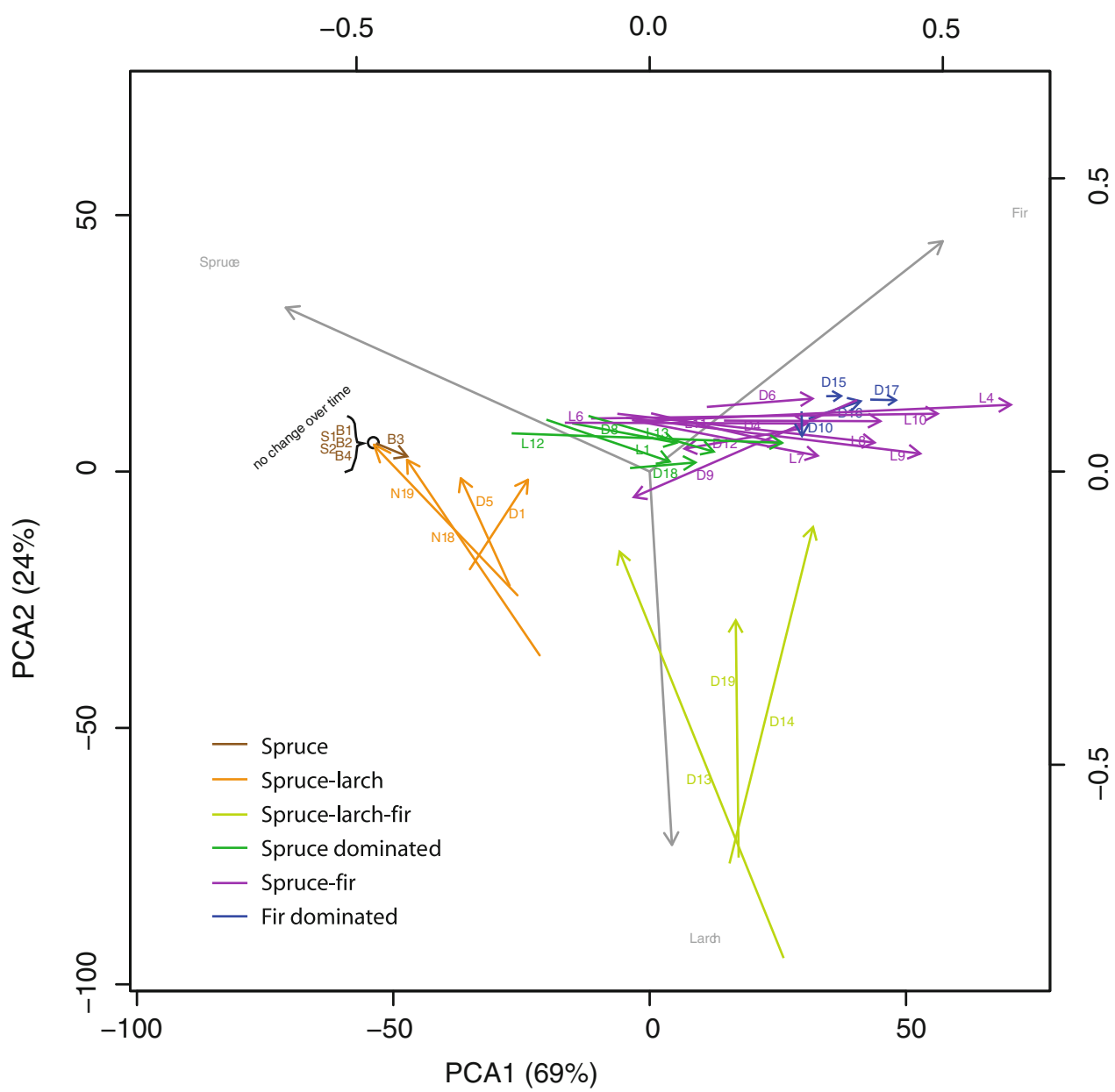

showed hardly any, and pure spruce stands no differences at all between under- and overstory species composition.

Temporal trend in tree species composition

The PCA of overstory tree species composition for the first and the last inventory (Fig. 7), showing the temporal dynamics of species composition, generally confirmed the results of Fig. 6. The first axis, accounting for $58 \%$ of the variation in species composition, spanned a gradient from spruce to fir and larch. The second axis described a gradient from fir across spruce to larch, and accounted for $41 \%$ of the variation. The plots within a cluster were well confined and similarly placed in ordination space, as shown in Fig. 6 for the first inventory. The general developmental trend showed an increase in fir dominance for most plots that were characterized by mixed spruce-fir stands in the first inventory (Fig. 7, Table 2). Spruce-larch stands, however, tended to increased spruce dominance, in some spruce-larch-fir stands larch continued to dominate, whereas plots D18 and L6 showed an increase in spruce dominance. The pure spruce plots and, albeit to a smaller extent, the fir-dominated plots showed no or hardly any change in species composition over time.

The same analysis for the tree species composition of the understory revealed a similar pattern (results not shown). However, the results of the understory were more fuzzy, indicating a higher variability of the understory species through competitive sorting, ultimately revealing the result of this process in the future overstory species composition.

\section{Discussion}

Inferring developmental phases from stand structure and species composition

With our analyses, we aimed to evaluate the validity of Leibundgut's (1993) scheme of the dynamics of mountain spruce-fir forests (Fig. 1a). Implicitly, it assumes distinct phases of forest succession that differ in species composition (cf. Finegan 1984). Based on the observed species composition, we were able to identify six fairly distinct groups of stands along a gradient (Austin and Smith 1989) from spruce-larch and spruce-larch-fir stands (early 
Fig. 7 Principal components analysis (PCA) of overstory tree species composition (Importance Value) for first and last inventory, showing the temporal dynamics of species composition. Note that the time elapsed for the trajectories shown varies between permanent plots. Colors according to groups from cluster analysis. Vectors for major tree species are marked in grey

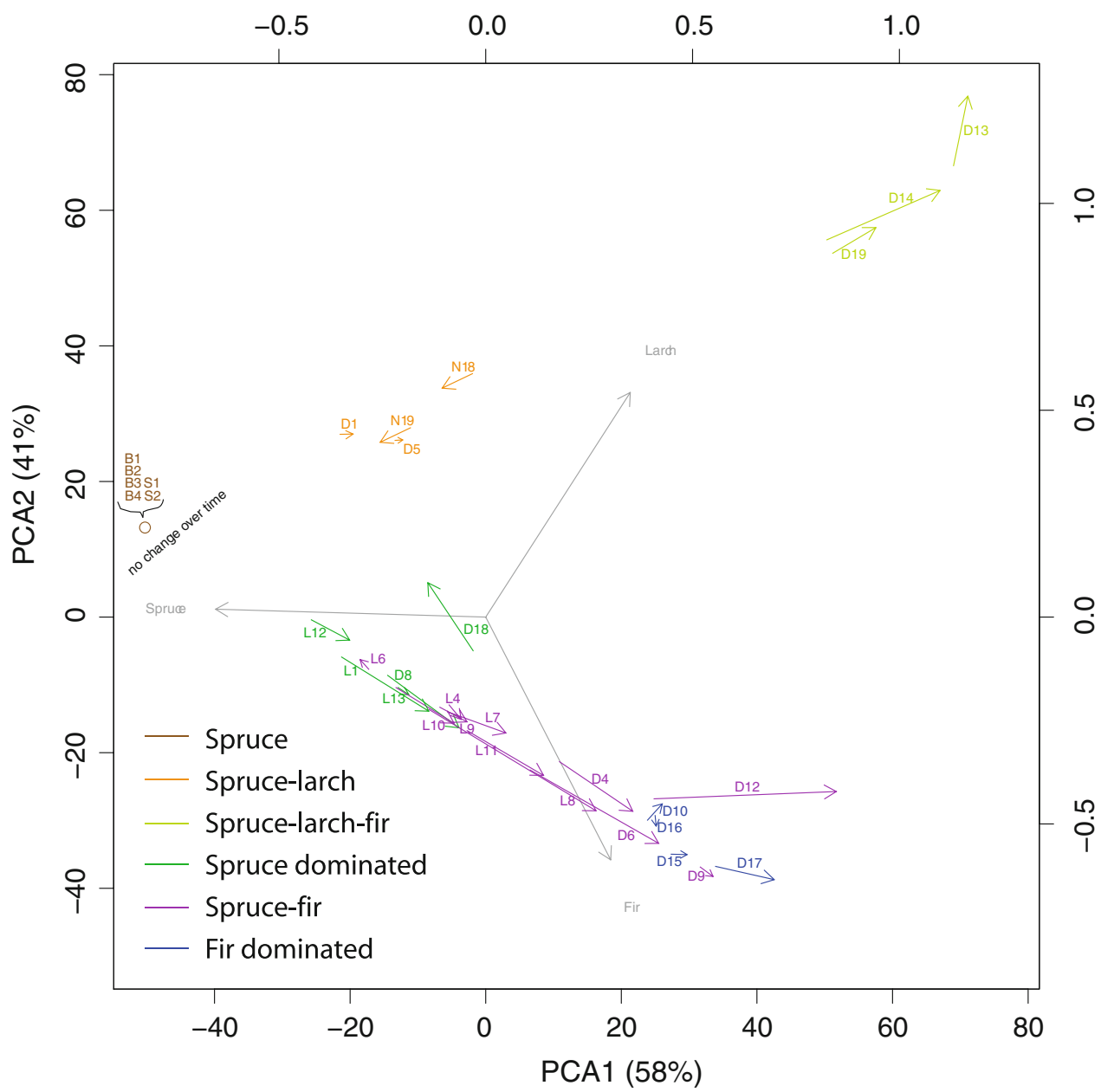

successional phases sensu Leibundgut) across sprucedominated and spruce-fir stands (mid-successional) to pure spruce and fir-dominated stands (late successional; cf. Fig. 1b). In this regard, the results of our cluster analysis provide a quantitative identification of the developmental stages described in Leibundgut's scheme, which were, in the original study, mostly based on qualitative insights.

In addition to these purely compositional aspects, we found that the structure of spruce-larch and spruce-larch-fir stands (the early successional phases) as well as the pure spruce stands (late successional) was characterized by distinct attributes in terms of their diameter distribution and the SI (structural index), again supporting Leibundgut's conjectures and evidence from other studies (Bončina 1998; Burrascano et al. 2008; Korpel' 1995; Mayer and Neumann 1981). Additional stand structural attributes such as basal area, total stem numbers, and numbers of dead trees, which are well-established proxies for assessing the successional stage of forest stands (Mayer and Neumann 1981), confirm our classification of the early successional phases (spruce-larch and spruce-larch-fir): the high number of living stems, the low amount of dead trees, and the low basal area all suggest that these stands represent an early phase of the successional cycle (Mayer and Neumann 1981). This interpretation is further supported by the range of Shannon evenness values (Table 4): the within-cluster variability of the diameter distribution is higher for early successional plots than for late successional ones, which is congruent with the fact that early successional plots can show quite differing diameter distributions, depending whether the plot developed after an abrupt or large-scale dieback or rather through a gradual and small-scale dieback of the old stand (Fig. 1b, pathways I vs. II). In late successional plots, however, tree growth and the resulting competition leads over time to a homogenization of the diameter distributions between plots.

The pure spruce stands have a structure typical for the late successional phase, featuring low stem numbers and a homogeneous dbh distribution (Fig. 4; Holeksa et al. 2007; Korpel' 1995). In the spruce forest Bödmerenwald, the short growing season and low air temperatures amidst a rough karst landscape are likely reasons for the absence of fir (Ellenberg 1996). In Scatlè, the high altitude (>1,600 m a.s.l.) and the low insolation in the narrow, incised valley 
lead to low temperatures and frequent frost occurrence, which may prevent fir from thriving there (Ellenberg 1996). In regions where fir is absent due to climatic limitations, pure spruce forests replace the fir-dominated stands at the end of the successional cycle, as found in our study and as suggested by other authors (Ellenberg 1996; Ott et al. 1997).

The mixed spruce-fir stands (spruce-dominated, firdominated and spruce-fir stands) could not be separated clearly from each other, neither based on their diameter structure nor by the location of their SI. We propose that this decoupling of composition and structure indicates that these stands are likely to be in closely related phases of the successional cycle, despite the distinct differences in the relative abundance of fir and spruce. The structural attributes of these stands are heterogeneous within their cluster, and the overlap between the SI values for these three clusters is considerable (Fig. 5), suggesting that they belong to different, but functionally similar successional phases. Despite the heterogeneity within the clusters, the general trend of the mean values per cluster indicates an increase in basal area and an increase in the number of large trees from early optimum (spruce-dominated) to mid-optimum (spruce-fir) and late optimum/old growth (fir-dominated), which is consistent with Leibundgut's classification.

When Leibundgut's scheme (Fig. 1a) is linked to the cluster groups of our analysis (Fig. 3), a generalized successional sequence based on species composition can be described as follows (Fig. 1b): larch forest (pioneer phase $a$, not investigated in our study), spruce-larch (transition phase b.I), or alternatively, spruce-larch-fir (transition phase b.II)-spruce-dominated (early optimum c.I)spruce-fir (early optimum c.II or mid-optimum $d$ ) - firdominated (late optimum $e$ and old-growth phase $f$ ).

This scheme (Fig. 1b) is in line with earlier studies emphasizing the importance of the spatial extent of disturbances for determining the pathway in early succession (Kimmins 2004; Oliver and Larson 1996; Spies and Franklin 1989). The structure and composition of the early optimum phase seem to be determined mainly by the development pathway during the beginning of the successional cycle (pathways I vs. II in Fig. 1b). The temporal trend from the spruce-larch forest (1) to the spruce-dominated forest (3) can be seen clearly in Fig. 7, whereas the transition from the spruce-larch-fir forest (2) to the sprucefir forest (4) was less clear. In the absence of large-scale synchronizing events, well-structured spruce-fir stands (4) are likely to emerge in the early optimum phase (Fig. 1b, pathway II). As indicated by the PCAs (Figs. 6, 7), these forests gradually develop toward fir-dominated late successional stands (5). However, when the stands are subject to a more synchronous development, which may be the case after the occurrence of large-scale disturbances (natural, or legacies of former clearcutting; pathway I), the early optimum phase consists of spruce-dominated forests (3) that developed from spruce-larch forests (1), as shown in the PCAs (Figs. 6, 7). The temporal development (Figs. 6, 7) further suggests that in these forests, fir emerges only gradually and does not dominate until the late optimum phase (5). In the latter case (pathway I), the occurrence of a pioneer phase seems to play a crucial role, where pioneer species such as larch first occupy the open space, gradually followed by spruce and, at a later stage, fir.

In regions with higher air humidity (fog, cloud cover) and therefore lower summer insolation, larch is absent almost entirely (Ellenberg 1996). These conditions prevail in the northern pre-Alps, represented by Leihubelwald and Bödmerenwald in our study. Here, other species such as rowan (Sorbus aucuparia), sycamore (Acer pseudoplatanus), or Scots pine (Pinus sylvestris) may form the pioneer phase (Ott et al. 1997). However, due to a lack of representative plots in our data set, we were not able to investigate this early successional pathway in more detail.

The late optimum and dieback phases were again clearly characterized based on stand structure (low stem numbers, presence of large dbh) and the dominance of fir or, if fir is absent, pure spruce forests (as in the case of Scatlè and Bödmerenwald). Although our data were consistent with the Leibundgut classification, the rather detailed subclassification within the optimum phase described by Leibundgut (1993; early, mid-, and late optimum) could not be supported.

\section{Temporal development inferred from long-term data}

The observed temporal development of the permanent plots largely confirms Leibundgut's succession scheme (Fig. 1a). The early successional stands with spruce-larch mixtures showed an increase in spruce abundance. Although spruce-larch-fir stands featured an increase in larch dominance in the overstory, their understory (lower third of canopy) was dominated by spruce and an increasing share of fir. This is a clear indicator that they will develop toward dominance by spruce and fir, unless a major disturbance would prevent the understory trees from reaching maturity. In all other stands, fir increased in dominance, with the largest changes in spruce-dominated and spruce-fir stands, whereas the shortest gradients in the multivariate analysis, and hence the smallest changes in species composition occurred in stands that are dominated by fir already.

Using the results of the analysis of the compositional changes over time (Fig. 7), we elucidated the sequence of successional phases, and these results are further supported 
by the changes in over- and understory species composition (Fig. 6). Additional corroboration is provided by the temporal development of stand structural attributes, such as a lack of trees with large dbh and the small numbers of dead trees for the early successional phases (spruce-larch and spruce-larch-fir), the decrease in basal area and the relatively high abundance of large trees (dead and alive) in late successional stands (fir-dominated and pure spruce stands, cf. Table 3). Although Burrascano et al. (2008) claim that species composition can be used as surrogate for stand structure and function, we found no clear relationship between species composition and stand structure in our data during the optimum phase(s).

Although the forests investigated here differ strongly in climatic and soil conditions (Table 1), their stand attributes and the temporal development of their permanent plots fit quite well into a single successional scheme (Fig. 1b). Thus, while site conditions such as the temperature and moisture regime clearly determine which tree species can grow (cf. complete lack of fir in Bödmerenwald and Plan Praspöl, or the lack of larch in Leihubelwald and Bödmerenwald), succession follows common trajectories in the investigated mountain spruce-fir-forests, at least over those parts of the successional cycle that could be investigated here.

\section{Limitations and research recommendations}

Although we had a large data set consisting of 36 permanent plots distributed over five forest reserves, there are some methodological limitations to our approach. With respect to especially the high structural heterogeneity of mixed spruce-fir forests, two important factors have to be taken into account.

First, in our study, most permanent plots were smaller than 1 ha, which reduces the likelihood of capturing the full range of structural conditions that characterize natural forests (D'Amato et al. 2008; Rubin et al. 2006). Nevertheless, we believe that by incorporating 36 permanent plots, we were able to capture the typical characteristics and much of the range of variability that is characteristic of the respective forest ecosystems. Moreover, the analysis of large plots bears the risk that within-plot structural differences remain undetected if small-scale disturbances prevail, which is probably the case for those forests in our sample in which fir is present (Leibundgut 1993; Zukrigl 1991).

Second, disturbances such as windthrow and bark beetles, which can be important for structuring spruce-fir forests (Brang et al. 2006; Ott et al. 1997), were not incorporated explicitly in our study, but they clearly had an influence on stand structure in at least 13 permanent plots. The two successional pathways clearly emerging in our study do not preclude the existence of further pathways. Nevertheless, we are confident that we identified the two main paths of forest development for this forest type, since such a clear pattern emerged from the wide range of stand characteristics represented by our data. However, our failure to differentiate between the later phases (early, mid-, and late optimum) may be due to scattered disturbances that may have occurred predominantly in spruce-fir- and firdominated stands.

Overall, our analysis shows the high value of long-term data from a wide variety of sites for elucidating stand structural attributes and successional pathways in mountain forests. To further investigate mechanisms and patterns of stand dynamics, to identify the prevailing disturbance regime(s) that facilitate regeneration (gap size and disturbance intervals), and to learn more about species co-existence (e.g., species replacement patterns), spatial stand information would be a valuable amendment to the existing inventory data (cf. Busing 1996, 1998, 2005). The ongoing and future inventory campaigns in the Swiss forest reserve network will therefore include such information (Brang et al. 2008).

The available inventory data from Swiss forest reserves do not cover lying dead wood. Burrascano et al. (2008) showed that certain dead wood variables (e.g., amount and type of coarse woody debris) are strongly linked to the variation in species composition. Complementing the inventory data with information on lying dead wood and conducting more detailed measurements on the standing dead trees could possibly enable us to identify the missing link between species composition and stand structural attributes (dead wood variables) for the optimum phase of stand succession; these investigations are planned as a component of the future monitoring effort in the Swiss forest reserves (Brang et al. 2008).

\section{Conclusions}

The monitoring data from five Swiss mountain forest reserves allowed us to quantify medium- and long-term changes in stand structure and species composition and to compare them with a succession scheme for Norway spruce-silver fir forests that is widely used in Europe (Leibundgut 1993).

For the early and late successional phases, we found a clear relationship between stand structure (dbh distributions) and species composition. Our results suggest two main pathways of early succession, which depend on the characteristics of the disturbances that initialize stand breakdown and regeneration. While large-scale synchronizing events lead to homogeneous spruce-dominated stands in the early optimum phase, small-scale breakdown 
events lead to well-structured spruce-fir stands. In contrast to Leibundgut (1993), who described clearly distinguishable optima sub-phases, we did not find a relationship between stand structure and species composition for the early, mid-, and late optimum phases. We conclude that the spatial extent of disturbances in spruce-fir forests is of high importance for determining the pathway in early succession, which in turn dictates the speed of succession toward fir dominance in the late optimum and old-growth phases.

Although the reserves investigated here are characterized by highly different climate and soil conditions, the temporal development of the permanent plots fits quite well into a single successional scheme. This suggests that for spruce-fir mountain forests, the life-history strategies of the involved species may influence the emerging successional trajectories more strongly than the site conditions per se.

\section{References}

Austin MP, Smith TM (1989) A new model for the continuum concept. Vegetatio 83:35-47

Bončina A (1998) Stand dynamics of the virgin forest Rajhenavski Rog (Slovenia) during the past century. In: Diaci J (ed) Virgin forests and forest reserves in central and East European Countries. COST Action E4 management committee and working groups meeting. University of Ljubljana, Ljubljana, pp 95-110

Brang P, Schönenberger W, Frehner M, Schwitter R, Thormann JJ (2006) Management of protection forests in the European Alps: an overview. For Snow Landsc Res 80:23-44

Brang P, Commarmot B, Rohrer L, Bugmann H (2008) Monitoringkonzept für Naturwaldreservate in der Schweiz. Eidg. Forschungsanstalt für Wald, Schnee und Landschaft WSL, Birmensdorf \& Professur Waldökologie, ETH Zürich. http://www.wsl.ch/publik ationen/pdf/8555.pdf Published online: February 2008

Burrascano S, Lombardi F, Marchetti M (2008) Old-growth forest structure and deadwood: are they indicators of plant species composition? A case study from central Italy. Plant Biosyst $142: 313-323$

Busing RT (1996) Estimation of tree replacement patterns in an Appalachian Picea-Abies forest. J Veg Sci 7:685-694

Busing RT (1998) Composition, structure and diversity of cove forest stands in the Great Smoky Mountains: a patch dynamics perspective. J Veg Sci 9:881-890

Busing RT (2005) Tree mortality, canopy turnover, and woody detritus in old cove forests of the southern Appalachians. Ecology 86:73-84

Butler Manning D (2007) Stand structure, gap dynamics and regeneration of a semi-natural mixed beech forest on limestone in central Europe-a case study. Dissertation, Albert-LudwigsUniversität, Freiburg im Breisgau

Clements FE (1936) Nature and structure of the climax. J Ecol 24:252-284

Commarmot B, Bachofen H (2005) Structures of virgin and managed beech forests in Uholka (Ukraine) and Sihlwald (Switzerland): a comparative study. For Snow Landsc Res 79:45-56

Coomes DA, Allen RB (2007) Mortality and tree-size distributions in natural mixed-age forests. J Ecol 95:27-40

D'Amato AW, Orwig DA, Foster DR (2008) The influence of successional processes and disturbance on the structure of Tsuga canadensis forests. Ecol Appl 18:1182-1199
Ellenberg H (1996) Vegetation Mitteleuropas mit den Alpen in ökologischer, dynamischer und historischer Sicht, 5th edn. Ulmer, Stuttgart

Ellenberg H, Klötzli F (1972) Waldgesellschaften und Waldstandorte der Schweiz. Mitt Schweiz Anst Forst Versuchswes 48:388 930

Emborg J (1998) Understorey light conditions and regeneration with respect to the structural dynamics of a near-natural temperate deciduous forest in Denmark. For Ecol Manag 126:83-95

Finegan B (1984) Forest succession. Nature 312:109-114

Franklin JF (1989) Importance and justification of long-term studies in ecology. In: Likens GE (ed) Long-term studies in ecology. Springer, New York, pp 3-19

Giraudoux P (2008) Pgirmess: data analysis in ecology. VR package version 1.3 .7

Gleason HA (1939) The individualistic concept of the plant association. Am Midl Nat 21:92-110

Gross D (1982) Einfluss von Hochstaudenvorkommen auf die natürliche Verjüngung von Fichte und Tanne in einem Naturwaldreservat (Leihubel/Giswil). Diploma-Thesis, ETH, Zürich

Heiri C, Wolf A, Rohrer L, Bugmann H (2009) Forty years of natural dynamics in Swiss beech forests: structure, composition and the influence of former management. Ecol Appl 19:1920-1934

Holeksa J, Saniga M, Szwargrzyk J, Dziedzic T, Ferenc S, Wodka M (2007) Altitudinal variability of stand structure and regeneration in the subalpine spruce forest of the Pol'ana biosphere reserve, Central Slovakia. Eur J For Res 126:303-313

Horvat I, Glavac V, Ellenberg H (1974) Vegetation Südosteuropas. Gustav Fischer-Verlag, Stuttgart

Kimmins JP (2004) Emulating natural forest disturbance. In: Perera $\mathrm{AH}$, Buse LJ, Weber MG (eds) Emulating natural forest landscape disturbances. Columbia Press, New York, pp 8-28

Koop H, Hilgen P (1987) Forest dynamics and regeneration mosaic shifts in unexploited beech (Fagus sylvatica) Stands at Fontainebleau (France). For Ecol Manag 20:135-150

Korpel' Š (1995) Die Urwälder der Westkarpaten. Gustav Fischer Verlag, Stuttgart

Kuoch R (1954) Wälder der Schweizer Alpen im Verbreitungsgebiet der Weisstanne. Mitt Schweiz Anst Forst Versuchswes 30: 133-260

Legendre P, Legendre L (1998) Numerical ecology, second english edition. Elsevier Science B.V., Amsterdam

Leibundgut H (1959) Über Zweck und Methodik der Struktur- und Zuwachsanalyse von Urwäldern. Schw Z Forstw 110:111-124

Leibundgut H (1962) Richtlinien für die Aufnahme von Waldreservaten. Unpublished report. Institut für Waldbau ETH Zurich, Zurich

Leibundgut H (1982) Europäische Urwälder der Bergstufe. Verlag Paul Haupt, Bern, Stuttgart

Leibundgut H (1993) Europäische Urwälder. Haupt, Bern

Lexerød NL, Eid T (2006) An evaluation of different diameter diversity indices based on criteria related to forest management planning. For Ecol Manag 222:17-28

Leyer I, Wesche K (2007) Multivariate Statistik in der Ökologie. Springer, Berlin

Mayer H (1974) Wälder des ostalpenraumes. Gustav Fischer-Verlag, Stuttgart

Mayer H, Neumann M (1981) Struktureller und entwicklungsdynamischer Vergleich der Fichten-Tannen-Buchen-Urwälder Rothwald/Niederösterreich und Čorkova Uvala/Kroatien. Forstwiss Centbl 100:111-132

Meyer P, Schulte U, Balcar P, Kölbel M (2000) Entwicklung der Baumarten- und Strukturdiversität in Buchen-Naturwaldreservaten. Buchen-Naturwaldreservate-unsere Urwälder von morgen, Recklinghausen, Natur- und Umweltschutz-Akademie des Landes Nordrhein-Westfalen 
Neumann M, Starlinger F (2001) The significance of different indices for stand structure and diversity in forests. For Ecol Manag 118:91-106

Oliver CD, Larson BC (1996) Forest stand dynamics, updated edn. Wiley, New York

Ott E, Frehner M, Frey HU, Lüscher P (1997) Gebirgsnadelwälder: praxisorientierter Leitfaden für eine standortgerechte Waldbehandlung. Verlag Paul Haupt, Bern

Parker GR, Leopold DJ, Eichenberger JK (1985) Tree dynamics in an old-growth, deciduous forest. For Ecol Manag 11:31-57

Parolini JD (1995) Zur Geschichte der Waldnutzung im Gebiet des heutigen Schweizerischen Nationalparks. Dissertation, ETH Zurich

Peterken GF (1996) Natural woodland: ecology and conservation in northern temperate regions. Cambridge University Press, Cambridge

Pickett STA, Cadenasso ML, Meiners SJ (2009) Ever since Clements: from succession to vegetation dynamics and understanding to intervention. Appl Veg Sci 12:9-21

Piovesan G, Di Filippo A, Alessandrini A, Biondi F, Schirone B (2005) Structure, dynamics and dendroecology of an old-growth Fagus forest in the Apennines. J Veg Sci 16:13-28

Podlaski R (2004) A developmental cycle of the forest with fir (Abies alba Mill.) and beech (Fagus sylvatica $\mathrm{L}$.) in its species composition in the Swietokrzyski National Park. J For Sci 50:55-66

R Development Core Team (2008) R: a language and environment for statistical computing. V2.7.1. R Foundation for Statistical Computing, Vienna

Remmert H (1991) The mosaic-cycle concept of ecosystems-an overview. The mosaic-cycle concept of ecosystems, ecological studies, vol 85. Springer, Berlin

Rubin BD, Manion PD, Faber-Langendoen D (2006) Diameter distributions and structural sustainability in forests. For Ecol Manag 222:427-438
Shannon CE, Weaver W (1949) The mathematical theory of communication. University of Illinois Press, Urbana

Siegel S, Castellan NJ (1988) Nonparametric statistics for the behavioral sciences, 2nd edn. McGraw-Hill, New York

Spies TA, Franklin JF (1989) Gap characteristics and vegetation response in coniferous forests of the Pacific Northwest. Ecology 70:543-545

Tabaku V (2000) Struktur von Buchen-Urwäldern in Albanien im Vergleich mit deutschen Buchen-Natruwaldreservaten und Wirtschaftswäldern. Dissertation, Georg-August-Universität, Göttingen

Thornton PE, Running SW, White MA (1997) Generating surfaces of daily meteorological variables over large regions of complex terrain. J Hydrol 190:214-251

Tilman D (1987) Secondary succession and the pattern of plant dominance along experimental nitrogen gradients. Ecol Monogr $57: 190-214$

Van der Maarel E (2005) Vegetation ecology. Blackwell Publishing, Oxford

Walentowski H (1998) Die Weisstannen-Waldgesellschaften Bayerns - eine vegetationskundliche Studie mit europäischem Bezug, mit waldbaulichen Anmerkungen und naturschutzfachlicher Bewertung. Dissertationes botanicae, vol 291. Cramer, Berlin

Watt AS (1947) Pattern and process in the plant community. J Ecol $35: 1-22$

Wohlgemuth T, Moser B, Brändli UB, Kull P, Schütz M (2008) Diversity of forest plant species at the community and landscape scale in Switzerland. Plant Biosyst 142:604-613

Wolf A (2005) Fifty year record of change in tree spatial patterns within a mixed deciduous forest. For Ecol Manag 215:112-223

Zukrigl K (1991) Succession and regeneration in the natural forests in central Europe. Geobiosis 18:202-208 